WISSENSCHAFTSZENTRUM BERLIN FÜR SOZIALFORSCHUNG

SOCIAL SCIENCE RESEARCH CENTER BERLIN

\author{
Ela Glowicka *
}

\title{
Bailouts in a Common Market: \\ A Strategic Approach
}

* WZB - Wissenschaftszentrum Berlin

SP II $2005-20$

November 2005

ISSN Nr. $0722-6748$

Research Area

Markets and Political Economy

Research Unit

Competitiveness and Industrial Change
Forschungsschwerpunkt

Markt und politische Ökonomie

Abteilung

Wettbewerbsfähigkeit und industrieller Wandel 
Zitierweise/Citation:

Ela Glowicka, Bailouts in A Common Market: A Strategic Approach, Discussion Paper SP II 2005 - 20, Wissenschaftszentrum Berlin, 2005.

Wissenschaftszentrum Berlin für Sozialforschung $\mathrm{gGmbH}$, Reichpietschufer 50, 10785 Berlin, Germany, Tel. (030) 25491 - 0 Internet: www.wz-berlin.de 


\section{ABSTRACT}

\section{Bialouts in a Common Market: A Strategic Approach*}

by Ela Glowicka

Governments in the EU grant Rescue and Restructure Subsidies to bail out ailing firms. In an international asymmetric Cournot duopoly we study effects of such subsidies on market structure and welfare. We adopt a common market setting, where consumers from the two countries form one market. We show that the subsidy is positive also when it fails to prevent the exit. The reason is a strategic effect, which forces the more efficient firm to make additional costreducing effort. When the exit is prevented, allocative and productive efficiencies are lower and the only gaining player is the rescued firm.

Keywords: subsidies, asymmetric oligopoly, exit, European Union

JEL Classification: F13, L13, L52.

ZUSAMMENFASSUNG

\section{Bail-out in gemeinsamen Märkten: Ein strategischer Ansatz}

Die Regierungen der EU gewähren staatliche Beihilfe zur Rettung und Umstrukturierung von Unternehmen in Schwierigkeiten. In einem internationalen asymmetrischen Cournot-Duopol werden die Wohlfahrtseffekte und die Konsequenzen solcher Beihilfe für die Marktstruktur analysiert. Grundannahme ist ein gemeinsamer Markt, auf dem Verbraucher aus zwei Ländern zusammenkommen.

Es wird gezeigt, dass die optimale Beihilfe positiv ist, auch wenn der Marktaustritt einer Firma nicht verhindert werden kann. Der Grund hierfür ist ein strategischer Effekt, der die effizientere Firma zu einer zusätzlichen kostenreduzierenden Maßnahme veranlasst. Wird der Marktaustritt verhindert, sind Allokations- und Produktionseffizienzen geringer, und der einzige aufholende Teilnehmer ist die gerettete Firma.

I am very grateful to Jos Jansen for his comments on an earlier version of this paper. I also thank Paul Heidhues, J. Peter Neary, Lars-Hendrik Röller, Oz Shy and participant of ETSG 2005 conference for helpful discussions. All remaining mistakes are mine. 


\section{Introduction}

Bailouts by governments in the EU are strictly regulated. Each time they must be approved by the EC Commission and the approval is conditional on a set of criteria gathered in the "Community Guidelines on State Aid for Rescuing and Restructuring Firms in

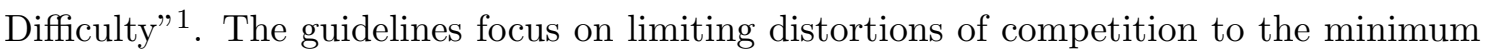
and give strict conditions for approvals of bailouts, e.g. one time -last time principle or a requirement of a proof of limited distortions in trade between member states caused by such a subsidy. Compensation measures are often imposed, such as selling a part of the market share to competitors of the beneficiary. The reason for these strict conditions is that $R \& R$ subsidies are particularly prone to distort competition among member states, as they may be acting against competitive forces which caused the exit. Such subsidies disadvantage competitors, who have to restructure with their own resources.

Strategic trade theory confirms this concern: literature started by Brander and Spencer (1983) shows that if countries grant subsidies strategically, they can improve the position of the subsidized national champion at the expense of the foreign firm. To the best of my knowledge, however, none of these models allows for a subsidy to bail out an exiting firm, since only interior solutions in the output game are analyzed. To analyze $R \& R$ subsidies we need to account for endogenous exit, which is our contribution to the literature.

In addition, strategic trade theory typically assumes that home and foreign firms compete in a third country, so the governments do not consider consumer surplus in their decisions about aid (an exception is Collie (2000) and (2002)). Still, consumer surplus is an important aspect in the debate on $R \& R$, since monitoring of state aid in the EU is said to take place in order to protect consumers' interests. ${ }^{2}$ Therefore, we incorporate the common market structure into the analysis: the subsidizing government maximizes not only profits of firms in her country, but also country's share in consumer surplus. Countries in the EU are very different in size, therefore asymmetry in this share is also accounted for.

Lahiri and Ono (1988) and Neary (1994) recommend social planners to tax high-cost

\footnotetext{
${ }^{1}$ Official Journal of the European Union, 2004/C 244/02

${ }^{2}$ EU competition policy and the consumer, Luxembourg: Office for Official Publications of the European Communities, 2004.
} 
and subsidize low-cost firms. Such policy creates a higher concentration in the market, but it improves welfare, since the firms with the increased market share are also more efficient. From this perspective, R\&R subsidy shifts resources in the "wrong" direction, because it is meant to increase market share of the inefficient firm. The problem is that individual governments maximize only a part of total EU welfare, so a bailout can be harmful for the EU, but still profitable for one country. We asses these externalities of R\&R subsidies on welfare in the EU in total and for member states of different sizes separately.

We consider a duopoly with two firms, each located in a different country, but selling in a common market. The firms have ex ante asymmetric unit production costs. They restructure in order to decrease these costs and then compete by setting quantities. Exit results from production inefficiency in one of the firms. In such a case the government can rescue the firm by subsidizing some additional restructuring and the bill is paid by consumers from the country of the aid beneficiary. When making this decision, the government maximizes welfare defined as profit of the firm and consumer surplus in the country. We are interested in two issues: the benefit from keeping the inefficient firm in the market and externalities of $\mathrm{R} \& \mathrm{R}$ subsidies on all players in the model. We also try to find a rationale for strict control of R\&R subsidies in the EU.

We have two main results. First, an R\&R subsidy fulfils two different roles. If cost differences are low and the subsidizing country small enough, the subsidy rescues the inefficient firm (we call this a successful rescue), increases welfare of the intervening country by increasing the profits of the aid beneficiary and decreasing the surplus of all consumers. If the cost asymmetry is higher, the subsidy is given, but it does not prevent the firm from exit (which we call a failed rescue). The subsidy is however only an apparent waste, since it provides a threat of no-exit to the efficient firm and forces this firm to cut its costs more than an unconstrained monopoly would. This strategic effect improves both productive and allocative efficiencies. The government is willing to grant such subsidy, because consumer surplus increases as the result of this intervention.

Second, externalities of the subsidy differ depending on whether the rescue succeeds or not. In a successful rescue, consumers and the competitor of the beneficiary are worse off, while the subsidized firm gains. In a failed rescue, consumers are better off and firm 2 loses. Externalities on welfare depend on the country's share in consumer surplus (we 
call it country's size). The size determines the amount of aid paid out and the way gains from the subsidy are distributed between member states. If the country is small, the government cares relatively more about the profits than about the price and therefore the subsidy is successful for a large set of initial cost asymmetries. Welfare of the other country and total welfare are reduced. When the subsidizing country is big enough, only failed rescues take place. Externality on welfare of the other country is negative, but total welfare increases thanks to higher consumer surplus.

If consumer surplus or total welfare were her objective, the Commission should ban $\mathrm{R} \& \mathrm{R}$ subsidies which are likely to prevent exit, since they result in a price rise and a loss in productive efficiency. Crucial assumptions for this result were asymmetries across countries and across firms. This is an explanation alternative to the argument by Collie (2000) and (2002) that distortionary taxation in a symmetric model may be the reason for aid prohibition. In this way we want to contribute to the discussion on state aid policy in the EU, which is at the top of the agenda of the current Competition Commissioner Neelie Kroes ${ }^{3}$.

\section{Model Setup}

There are two countries. Each country has one government and one firm. Firms produce a homogenous good, which is sold on a common market without barriers in trade. Governments maximize welfare defined as profit of the firm in their country and the country's share in consumer surplus. Let country 1's share in consumer surplus be $\alpha$ and country 2's share $1-\alpha$. Denoting welfare in country $i$ as $W_{i}$ we have:

$$
\begin{aligned}
& W_{1}=\pi_{1}+\alpha C S \\
& W_{2}=\pi_{2}+(1-\alpha) C S \\
& W=W_{1}+W_{2}=\pi_{1}+\pi_{2}+C S .
\end{aligned}
$$

Firms maximize profits. Production cost functions are linear with asymmetric marginal costs denoted by $c_{1}$ and $c_{2}$ and we assume $c_{1}>c_{2}$. This asymmetry is exogenous. Inverse

\footnotetext{
${ }^{3}$ Introductory Statement at EMAC Open Meeting of Coordinators, Feb. 3rd, 2005.
} 
demand is $P=P(x)$, where $x=x_{1}+x_{2}$ with $P^{\prime}(x)<0$. The game has three stages. First, the government with the less efficient firm commits to subsidize restructuring if the firm has to exit without help. Then firms restructure on their own and finally firms compete by setting quantities. Restructuring is modelled as process-R\&D: it means cutting marginal cost by $e_{i}$ at the cost of $\frac{d}{2} e_{i}^{2}$, where $d>0$. It is important to note that the cost of restructuring is the same for both firms and for the government. ${ }^{4}$ We solve for the subgame-perfect Nash equilibrium by backward induction.

If there is no exit, there is no subsidy and firms' profits are

$$
\pi_{i}=P(x) x_{i}-\left(c_{i}-e_{i}\right) x_{i}-\frac{d}{2} e_{i}^{2} \quad i=1,2 .
$$

As typically happens in asymmetric Cournot games, if the initial marginal cost difference is high enough, the less efficient firm exits and a monopoly of the more efficient one emerges in the equilibrium. Government 1 can perfectly anticipate when firm 1 will exit in the equilibrium. In such a case, the government can subsidize further restructuring in firm 1 by $\frac{d}{2} k_{1}^{2}$ and reduce marginal costs additionally by $k_{1}$. Two payoffs are changed (with subscript $s$ ):

$$
\begin{aligned}
\pi_{1 s} & =P(x) x_{1}-\left(c_{1}-e_{1}-k_{1}\right) x_{1}-\frac{d}{2} e_{1}^{2} \\
W_{1 s} & =\pi_{1 s}-\frac{d}{2} k_{1}^{2}+\alpha C S .
\end{aligned}
$$

This definition of subsidy is similar to definitions used in the literature in the sense that it affects marginal costs directly. ${ }^{5}$ On the other hand, R\&R subsidy differs from commonly used subsidy definitions, because with the subsidy the government gives her own restructuring technology to the firm. She behaves as an entrepreneur and actually makes some decisions, what gives country 1 a cost advantage since $\frac{d}{2} e_{1}^{2}+\frac{d}{2} k_{1}^{2}<\frac{d}{2}\left(e_{1}+k_{1}\right)^{2}$. In reality, transfer of technology often happens in $R \& R$ cases, since governments and public agencies actively participate in designing a restructuring plan or negotiating with unions.

\footnotetext{
${ }^{4}$ One could argue that restructuring is more expensive for the low-cost firm since it has no "slack" or X-inefficiency, so that for example parameter $d$ for this firm should be higher. It is a valid concern, since Aghion and Schankerman (2004) allow for such slack and find that the equilibrium can have totally different properties than in the symmetric case.

${ }^{5}$ Mollgaard (2004) is an exception, defining aid as a reduction in the cost of capital.
} 
Sometimes a government hires a consulting firm to do the job of preventing exit. Generally we can say that when bankruptcy is in sight, governments take unusual measures to save the firm and these unusual measures are the new restructuring technology.

Government 2 cannot subsidize, which is another asymmetry in the model and we introduce it in order to reflect the rules in the EU: only otherwise exiting firms can be subsidized and firm 2 in the equilibrium of our benchmark no-subsidy model never exits.

Finally, a comment on technical issues. Our problem is by nature asymmetric. Since asymmetric general models are difficult to solve, we make a compromise by choosing specific functional forms of both cost functions (linear and quadratic), leaving demand general and using linear demand case as an example. Welfare effects are presented only for the example of linear demand. This model structure is motivated by the fact that properties of the demand function seem to be crucial for optimal R\&D subsidies. For example, Lahiri and Ono (2004) show that, when firms are symmetric, the sign of the subsidy is the same as the sign of the second derivative of demand. We limit our attention to pure strategy equilibria.

\section{Benchmark Equilibrium: no subsidy}

As a benchmark for the rescue subsidy game we consider a two-stage game, where both governments are passive and their payoffs result only from actions of firms. Firms simultaneously choose restructuring level and then decide about output level. Since we do not exclude exit, which is an unusual aspect of this model, we will look at this game in some detail.

In the second stage of the game, first order conditions for duopoly equilibrium are

$$
P^{\prime}(x) x_{i}+P(x)-c_{i}+e_{i}=0 \quad i=1,2 .
$$

which implicitly define $x_{i}\left(e_{1}, e_{2}\right)$. We assume that second order conditions $P^{\prime \prime}(x) x_{i}+$ $2 P^{\prime}(x)<0$, and stability conditions $P^{\prime \prime}(x) x_{i}+P^{\prime}(x)<0$ and $\frac{\partial^{2} \pi_{i}}{\partial x_{i}^{2}}>\frac{\partial^{2} \pi_{i}}{\partial x_{i} \partial x_{j}}$ hold. Totally 
differentiating (7) and using the assumptions, we obtain comparative statics results:

$$
\frac{d x_{i}}{d e_{i}}>0 \quad \frac{d x_{j}}{d e_{i}}<0 \quad \frac{d x}{d e_{i}}>0
$$

which indicate that restructuring expands own and total output, while reducing competitor's output. That implies that competitor's market share is decreased. In the first stage, first order conditions ${ }^{6}$ are

$$
P^{\prime}(x) x_{i} \frac{\partial x}{\partial e_{i}}+\left(P(x)-c_{i}+e_{i}\right) \frac{\partial x_{i}}{\partial e_{i}}+x_{i}-d e_{i}=0 \quad i=1,2
$$

and using (7) we can simplify them to

$$
x_{i}+x_{i} P^{\prime}(x) \frac{\partial x_{j}}{\partial e_{i}}=d e_{i} \quad i=1,2 .
$$

The marginal cost of restructuring (right-hand side) equals the marginal revenue (lefthand side), which is composed of two effects. The direct effect is just a decrease of the production cost, represented here by $x_{i}$. The second expression represents the strategic effect restructuring has on the competitor's output. Since both derivatives in this expression are negative, their product is positive, so the strategic effect increases marginal revenue of restructuring.

Equations (7) and (10) implicitly define the equilibrium $x_{i}^{D}\left(c_{1}, c_{2}\right)$ and $e_{i}^{D}\left(c_{1}, c_{2}\right)$ (D stands for duopoly).

Comparing duopoly restructuring levels $e_{1}^{D}$ and $e_{2}^{D}$, Lahiri and Ono (2004) prove ${ }^{7}$ the following

Proposition 1 The firm with lower initial marginal cost invests more in restructuring.

Low-cost firm reduces marginal cost by more than the rival, so that the initial cost difference is magnified. This observation goes back to the hypothesis of Schumpeter that big firms are better innovators (in terms of production process) than high-cost firms, since they are able to exploit cost-cuts on a larger scale.

For $c_{1}-c_{2}$ sufficiently high, a monopoly of firm 2 is the equilibrium. There can be two

\footnotetext{
${ }^{6}$ We assume second order conditions to hold.

${ }^{7}$ The proof can be found on page 24 of the book.
} 
qualitatively different outcomes: blockaded monopoly, which operates unconstrained by the potential entry (here rather non-exit) of firm 1, and entry-deterring monopoly, where the competitor is strategically excluded from the market. First we consider a blockaded monopoly. First order condition in the output stage is

$$
P^{\prime}\left(x_{2}\right) x_{2}+P\left(x_{2}\right)-c_{2}+e_{2}=0
$$

which implicitly defines $x_{2}\left(e_{2}\right)$. We assume second order condition $P^{\prime \prime}+2 P^{\prime}<0$ to hold. Differentiating (11) with respect to $e_{2}$ and using the second order condition we find that

$$
\frac{d x_{2}}{d e_{2}}>0
$$

In the first stage, the first order condition ${ }^{8}$ is

$$
P^{\prime}\left(x_{2}\right) x_{2} \frac{\partial x_{2}}{\partial e_{2}}+\left(P\left(x_{2}\right)-c_{2}+e_{2}\right) \frac{\partial x_{2}}{\partial e_{2}}+x_{2}-d e_{2}=0
$$

and using (11) it boils down to a simple equation

$$
x_{2}=d e_{2} .
$$

In case of monopoly there is no strategic effect of $e_{2}$ on $x_{1}$, so the effect of restructuring is just the reduction of production cost. Equations (11) and (14) together define $x_{2}^{M}\left(c_{2}\right)$ and $e_{2}^{M}\left(c_{2}\right)$ (M stands for monopoly).

When entry-deterrence takes place, firm 2 increases its output above monopoly level to exclude the competitor. In such a situation, $x_{2}$ is at the level which nullifies $x_{1}\left(e_{1}, e_{2}\right)$ calculated from (7), that is $x_{2}$ such that

$$
\left[P^{\prime}\left(x_{1}+x_{2}\right) x_{1}+P\left(x_{1}+x_{2}\right)-c_{1}+e_{1}\right]_{x_{1}=0}=0,
$$

from which we get

$$
P\left(x_{2}\right)=c_{1}-e_{1} .
$$

\footnotetext{
${ }^{8}$ We assume second order conditions to hold.
} 
Optimal output of firm 1 is then 0 , and therefore also restructuring level is zero: $x_{1}^{E}=0$ and $e_{1}^{E}=0$ ( $E$ stands for entry-deterrence). Going back to equation (16) we get

$$
P\left(x_{2}^{E}\right)=c_{1}
$$

Firm 2 produces as much as is necessary to price the good at the marginal cost of the competitor and in this way enforces its exit. The optimal restructuring level leading to this output follows from equation (14):

$$
x_{2}^{E}=d e_{2}^{E} .
$$

\subsection{Linear Demand Example}

If inverse demand is linear, e.g. $p=1-x_{1}-x_{2}$, the equilibrium can be explicitly calculated. To simplify complex calculations, we fix the parameters $d$ and $c_{2}$. We choose $d=5$ so that all profit functions are concave and $c_{2}=0.4$ so that we avoid a number of corner solutions and focus exclusively on the role of the asymmetry in initial cost for the market structure in the equilibrium ${ }^{9}$. Let us define $\underline{c_{1}}=0.485749, \tilde{c_{1}}=0.532987$ and $\overline{c_{1}}=0.6667$.

Proposition 2 For $c_{1} \in\left(0.4, c_{1}\right)$ duopoly emerges in the equilibrium with optimal strategies:

$$
\begin{array}{ll}
e_{1}^{D}=4 \frac{17-26 c_{1}}{451} & x_{1}^{D}=\frac{15}{4} e_{1}^{D} \\
e_{2}^{D}=4 \frac{0.6+15 c_{1}}{451} & x_{2}^{D}=\frac{15}{4} e_{2}^{D} .
\end{array}
$$

Entry-deterring monopoly of firm 2 emerges when $c_{1} \in\left(\tilde{c_{1}}, \overline{c_{1}}\right)$. Optimal strategies are

$$
e_{2}^{E}=\frac{1-c_{1}}{5} \quad x_{2}^{E}=5 e_{2}^{E}
$$

For $c_{1} \in\left(\overline{c_{1}}, 1\right)$ equilibrium market structure is blockaded monopoly of firm 2 with optimal

\footnotetext{
${ }^{9}$ Qualitatively, we get the same results choosing any $d \in(4, \infty)$ and $c_{2} \in(0.2,0.5)$. For $c_{2}<0.2$ there are more and for $c_{2}>0.5$ less corner solutions to consider, but the mechanism is the same.
} 
strategies

$$
e_{2}^{M}=\frac{1}{15} \quad x_{2}^{M}=5 e_{2}^{M} .
$$

The proof can be found in the Appendix, but in order to build some intuition we present reaction functions of the three equilibrium market structures in the first stage of the game:

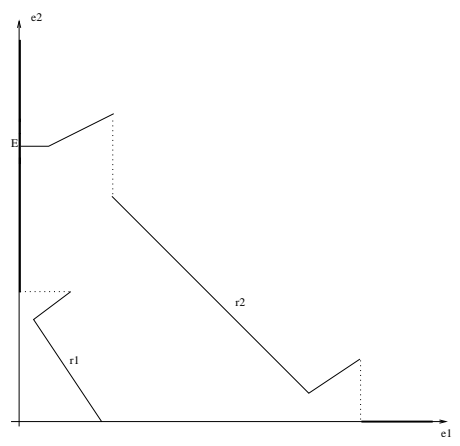

(a) monopoly

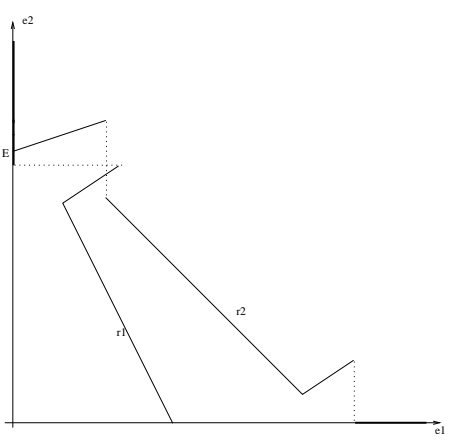

(b) entry-deterrence

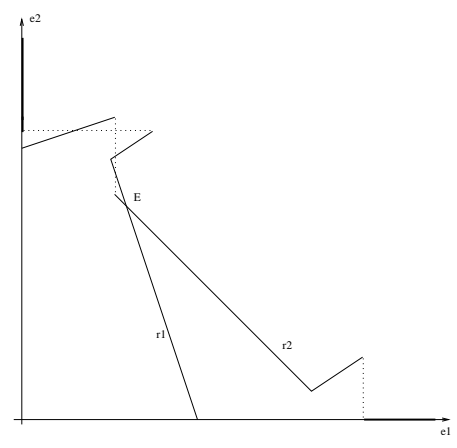

(c) duopoly

Figure 1: In the equilibrium of the benchmark game there are three possible market structures.

Figure 1(a) shows the case when firm 2 has a very high efficiency advantage. Its reaction function is composed of 5 pieces. For $e_{1}$ very low, best-reply of firm 2 is a blockaded monopoly with restructuring constant in $e_{1}$. When $e_{1}$ is higher, firm 2 deters entry of firm 1 by increasing its restructuring level. This is the second, increasing part of the reaction function. For higher $e_{1}$, best reply is accommodation, so that the outcome is duopoly. In that case the reaction function is decreasing. The fourth piece is where duopoly as a corner solution is the best-reply. Finally, if $e_{1}$ is too high, best reply is not to restructure and exit, so the reaction function coincides with $e_{1}$ axis. Firm 1's reaction function has only 3 pieces, since firm 1 has a higher initial production cost and neither monopoly nor entry-deterrence are achievable, but the logic is the same. Both reaction functions cut in point E, where firm 1 chooses to exit and firm 2 restructures at the monopoly level.

Figure 1(b) shows the case when firm 2 has a moderate efficiency advantage. Its reaction function is pushed to the left, so that monopoly part is not possible for positive 
$e_{1}$. The equilibrium is entry-deterrence by firm 2 , since firm 2's best-reply to $e_{2}=0$ is entry-deterring restructuring level, which is higher than in monopoly. Finally, figure 1(c) shows duopoly equilibrium, where downward-sloping parts of the reaction functions cut and both firms end up with positive restructuring and production.

Looking at the functional forms of the duopoly restructuring levels (19) and (20), we notice that the result exemplifies Proposition 1: for $c_{1}>0.4$ we have $e_{1}^{D}<e_{2}^{D}$, and the final cost difference is higher than initially. This result is robust to the definition of competition: Aghion and Schankerman (2004) got it for Salop model, Lahiri and Ono (2004) for Cournot duopoly with general demand, Escrihuela-Villar (2004) for n-firm Cournot competition with linear demand, Röller and Sinclair-Desgagne (1996) for two-market Cournot duopoly. In entry-deterrence outcome (16), however, $e_{2}^{E}$ decreases with $c_{1}$, since the bigger the initial cost difference, the bigger efficiency advantage of firm 2, so that less aggressive predatory behavior is sufficient to deter entry of firm 1 . This finding will be crucial in further analysis.

\section{Subsidy Equilibrium}

If the initial cost asymmetry is too big, firm 1 exits (in the example it happens for $c_{1}>\tilde{c_{1}}$ ). In the EU, government 1 could then subsidize some additional restructuring in firm 1 . We will introduce this possibility to the game by extending the benchmark model by a stage, where government 1 can choose to do it.

The new game has three stages. In the first stage, government 1 commits to subsidize firm 1's restructuring process with $s=\frac{d}{2} k_{1}^{2}$ in order to lower its marginal cost by $k_{1}$ if without help the firm exits. Government 2 is not allowed to subsidize. In the second stage firms choose their restructuring level and the subsidy is paid. In the third stage they compete á la Cournot. Such formulation of the game reflects the rules of the EU common market, where governments can subsidize restructuring of ailing firms and they usually get involved into restructuring process. The outcomes are denoted by a subscript $s$.

In the third stage, when duopoly emerges, first order conditions are

$$
\begin{array}{r}
P^{\prime}(x) x_{1}+P(x)-c_{1}+e_{1}+k_{1}=0 \\
P^{\prime}(x) x_{2}+P(x)-c_{2}+e_{2}=0 .
\end{array}
$$


We assume that second order conditions $P^{\prime \prime}(x) x_{i}+2 P^{\prime}(x)<0$ and stability conditions hold. Comparative statics is done analogously to the benchmark game and we conclude that

$$
\frac{d x_{1}}{d k_{1}}>0 \quad \frac{d x_{2}}{d k_{1}}<0 \quad \frac{d x}{d k_{1}}>0
$$

The subsidy works exactly like restructuring by firm 1 . It increases the output of the beneficiary at the cost of its more efficient competitor and the total output is also increased. This is the traditional profit-shifting effect of subsidies in strategic trade subsidy games.

In the second stage of duopoly, first order conditions are just like in the benchmark case:

$$
x_{i}+x_{i} P^{\prime}(x) \frac{\partial x_{j}}{\partial e_{i}}=d e_{i} \quad i=1,2 .
$$

Both first order conditions together implicitly define equilibrium outputs and restructuring as functions of $k_{1}$. Just as before, restructuring has a direct and a strategic impact on the marginal revenue.

In entry-deterrence, if the subsidy is positive, the increase of output in firm 2 must be such that

$$
P\left(x_{2}^{E s}\right)=c_{1}-k_{1} \text {. }
$$

This equation shows the strategic effect of the subsidy. The government changes the initial conditions of the game between the firms: firm 2 has to adapt its strategy to the lower initial cost of firm 1. Since demand is decreasing, we have $x_{2}^{E}<x_{2}^{E s}$. Firm 2 produces more output to deter firm 1 , because firm 1 is more efficient thanks to the subsidy.

In unconstrained monopoly, output and restructuring in firm 2 are the same as in the benchmark.

In the first stage, government 1 optimally chooses $k_{1}$. In case of duopoly welfare in country 1 is

$$
W_{1 s}\left(k_{1}\right)=P(x) x_{1}-\left(c_{1}-e_{1}-k_{1}\right) x_{1}-\frac{d}{2} e_{1}^{2}-\frac{d}{2} k_{1}^{2}+\alpha \int_{0}^{x^{D}}\left(P(x)-P\left(x^{D}\right)\right) d x
$$


and we further assume that it is concave. Optimal $k_{1}$ is the one which nullifies derivative of $W_{1 s}$ with respect to $k_{1}$ :

$$
x_{1}+x_{1} \frac{\partial e_{1}}{\partial k_{1}}+x_{1} P^{\prime}(x) \frac{\partial x_{2}}{\partial k_{1}}-\alpha x P^{\prime}(x) \frac{\partial x}{\partial k_{1}}=d\left(\frac{\partial e_{1}}{\partial k_{1}} e_{1}+k_{1}\right) .
$$

The above equation shows all effects of the subsidy on welfare in country 1 . The first term is the direct effect on the output in firm 1: marginal cost of production decreases so each unit of output brings higher revenue. The second term is the strategic effect on firm 1 , due to which firm 1 restructures more by its own. This is a consequence of Proposition 1., since when the subsidy is positive, firm 1 has lower initial marginal cost. The third term is the strategic effect on the other firm (selection or profit-shifting effect). In reaction to a positive subsidy, firm 2's output decreases and firm 1 grabs a bigger market share. The fourth term on the left-hand side of the equation reflects the price drop as the effect of the subsidy (competitive effect). The higher $k_{1}$, the lower the price, because total output increases. Summing up, as the result of the subsidy allocative efficiency is improved, but productive efficiency may be reduced due to the selection effect. The term on the righthand side is the marginal cost of restructuring and it consists of the subsidy cost which consumers have to pay, as well as the cost of restructuring paid by the firm which is higher than in the benchmark due to the positive subsidy.

If entry-deterrence is the equilibrium, government 1 chooses $k_{1}$ such that

$$
W_{1 s}=-\frac{d}{2} k_{1}^{2}+\alpha \int_{0}^{x_{2}^{E}}\left(P(x)-P\left(x_{2}^{E}\right)\right) d x
$$

is maximized. Again we assume that this function is concave with respect to $k_{1}$. The first order condition is

$$
\frac{\partial W_{1 s}}{\partial k_{1}}=-\alpha x_{2} P^{\prime}\left(x_{2}\right) \frac{\partial x_{2}}{\partial k_{1}}-d k_{1}=0 .
$$

We assumed that $P^{\prime}(x)$ is negative, we also know from (27) that $\frac{\partial x_{2}}{\partial k_{1}}$ is positive. Therefore, the derivative $\frac{\partial W_{1 s}}{\partial k_{1}}$ evaluated in $k_{1}=0$ is positive. Since $W_{1 s}$ is concave, $k_{1}$ satisfying (31) must be positive. We can conclude that in entry-deterrence the subsidy is positive. The government tries to bail the firm out, but the firm exits. 
Proposition 3 (Failed Rescue) If the equilibrium is entry-deterring monopoly of the more efficient firm, the RER subsidy to the exiting firm is positive.

Even when the less efficient firm exits for sure and the subsidy is nothing more than burning consumers' money, government 1 has a good reason to do it: the market is imperfectly competitive and the subsidy has a strategic effect on the efficient firm. This firm decreases the price so much, that even having paid for the subsidy, consumers in country 1 are better off. Consumers in country 2 gain even more, since they don't pay for the costly policy of government 1 .

\subsection{Linear Demand Example}

For the sake of brevity, we define the following terms:

$$
\begin{aligned}
& f_{1}(\alpha)=0.33359+0.0366975 \alpha-0.024098 \sqrt{(\alpha-28.168411)(\alpha+0.50916)} \\
& f_{2}(\alpha)=0.5829-0.109912 \alpha \\
& f_{3}(\alpha)=0.485749+0.10285 \alpha+0.062697 \sqrt{(\alpha-5)(\alpha-0.35357)} \text { for } \alpha \in(0,0.3535)
\end{aligned}
$$

$f_{4}(\alpha)=1-0.14907 \sqrt{5-\alpha}$

$f_{5}(\alpha)=0.56271+0.02856 \alpha-1.38407 \sqrt{\frac{(\alpha-28.1684)^{2}(\alpha-0.27334)}{153377-5445 \alpha}}$ for $\alpha \in(0.27334,1)$

$$
\begin{aligned}
f_{6}(\alpha) & =0.47224+0.0467 \alpha \\
m_{4} & =0.52709+0.02982 \alpha \quad m_{5}=0.532987+0.0934 \alpha
\end{aligned}
$$

and in the Appendix we prove

Proposition 4 Six different equilibrium outcomes emerge, depending on the parameters vector $\left(\alpha, c_{1}\right)$.

1. If condition $0.4<c_{1}<\min \left[f_{1}(\alpha), f_{6}(\alpha)\right]$ is fulfilled, entry-deterrence by firm 1 
emerges in the equilibrium with strategies

$$
k_{1}^{E 1}=c_{1}-0.229143 \quad e_{1}^{E 1}=0.12 \quad x_{1}^{E 1}=5 e_{1}^{E 1} .
$$

2. When $f_{1}(\alpha)<c_{1}<\min \left[m_{4}(\alpha), f_{5}(\alpha)\right]$, duopoly emerges with strategies

$$
\begin{array}{rlrl}
e_{1}^{D} & =4 \frac{17-26\left(c_{1}-k_{1}^{D}\right)}{451} & x_{1}^{D}=\frac{15}{4} e_{1}^{D} \\
e_{2}^{D}=4 \frac{0.6+15\left(c_{1}-k_{1}^{D}\right)}{451} & x_{2}^{D}=\frac{15}{4} e_{2}^{D} \\
k_{1}^{D}=\frac{-0.804028+1.22969 c_{1}-0.214158 \alpha+0.133849 c_{1} \alpha}{0.133849 \alpha-3.77031} &
\end{array}
$$

3. If $m_{4}(\alpha)<c_{1}<\min \left[f_{2}(\alpha), f_{3}(\alpha)\right]$, duopoly emerges as well, but the corner subsidy

$$
k_{1}^{D c}=c_{1}-0.485749
$$

is chosen instead of $k_{1}^{D}$.

4. For $\max \left[f_{2}(\alpha), f_{5}(\alpha), f_{6}(\alpha)\right]<c_{1}<m_{5}(\alpha)$, entry-deterrence by firm 2 emerges:

$$
k_{1}^{E 2 c}=c_{1}-0.532987 \quad e_{2}^{E 2}=\frac{1}{5}\left(1-c_{1}+k_{1}^{E 2 c}\right) \quad x_{2}^{E 2}=5 e_{2}^{E 2} .
$$

5. If $\max \left[f_{3}(\alpha), m_{5}(\alpha)\right]<c_{1}<f_{4}(\alpha)$, entry-deterrence by firm 2 emerges with strategies

$$
k_{1}^{E 2}=\frac{\alpha\left(1-c_{1}\right)}{5-\alpha} \quad e_{2}^{E 2}=\frac{1}{5}\left(1-c_{1}+k_{1}^{E 2}\right) \quad x_{2}^{E 2}=5 e_{2}^{E 2} .
$$

6. Finally, for $c_{1}>f_{4}(\alpha)$, firm 2 is a blockaded monopolist and the optimal subsidy is zero.

How does the subsidy actually work? Figure 2 helps to develop some intuition. Reaction functions of the benchmark game are depicted in black and those of the subsidy game in red.

Figure 2(a) shows a failed rescue. The benchmark equilibrium is entry-deterring monopoly of firm 2, denoted by E. Due to the subsidy, equilibrium is moved to point Es, which is also the entry-deterring monopoly of firm 2, but with a higher restructuring 


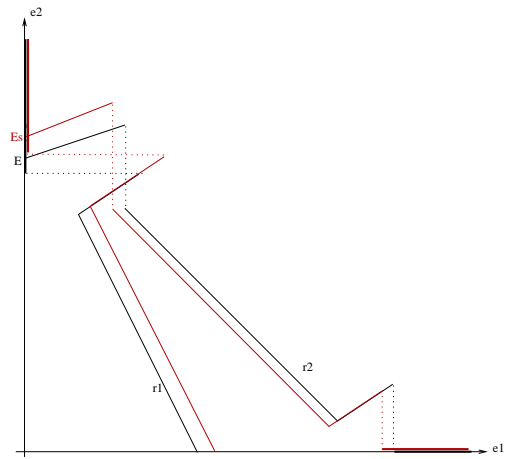

(a) failed rescue

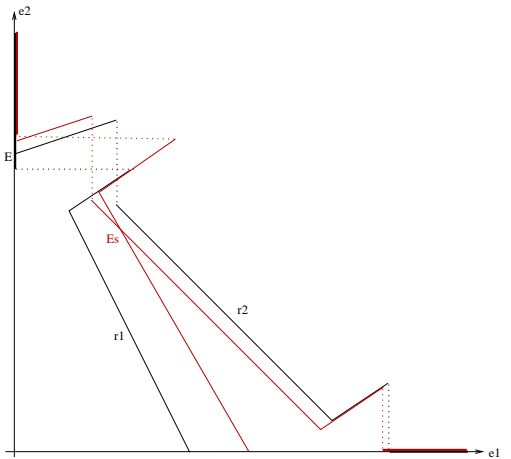

(b) successful rescue

Figure 2: The subsidy game has two very different outcomes.

level. Figure 2(b) illustrates a successful rescue: entry-deterrence equilibrium E changes into duopoly equilibrium Es, firm 1 is successfully rescued.

When $c_{1}>\tilde{c_{1}}$, firm 1 exits in the equilibrium of the benchmark model and only then the subsidy is legal. Therefore, we analyze the subsidy equilibrium for $c_{1}>\tilde{c_{1}}{ }^{10}$. Figure 3 shows the location of each market structure in the $\left(\alpha, c_{1}\right)$ space.

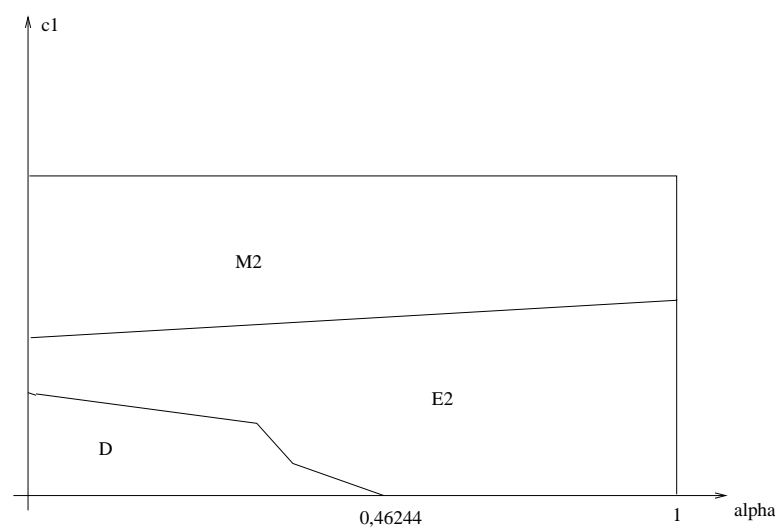

Figure 3: The subsidy game results in one of three market structures: duopoly (D), entrydeterrence by firm 2 (E2) or blockaded monopoly of firm 2 (M2).

Comparing this outcome with the equilibrium in the benchmark case allows us to make a few interesting observations. The first observation is a confirmation of Proposition 3: $k_{1}^{E 2 c}$ and $k_{1}^{E 2}$ are positive. In entry-deterrence of firm 2, government 1 still subsidizes firm

\footnotetext{
${ }^{10}$ We skip the set $c_{1} \in\left(\underline{c_{1}}, \tilde{c_{1}}\right)$ since they have no equilibrium in the benchmark.
} 
1 in order to achieve the desired strategic effect on firm 2. This effect consists of making firm 1 a little more efficient, so that firm 2 has to be more aggressive in cost-cutting to deter entry of firm 1. The result is a lower production cost and a lower price, which is beneficial for consumers in both countries.

The second observation is that duopoly is now more common: more parameter vectors result in duopoly. These vectors, which in the benchmark ended up with monopoly and with the subsidy lead to duopoly, guarantee a successful rescue. In these cases the original purpose of the subsidy is achieved: the less efficient firm is rescued from exit. Note that the lower $\alpha$, the larger the set of $c_{1}$ which leads to successful rescue, while for $\alpha>0.462443$ duopoly is not possible at all. That is because a big country has bigger incentives to subsidize an unsuccessful rescue: there are more consumers who gain from the decline of the price and are ready to pay for the subsidy. That implies that the strategic effect on the competing firm is stronger. From this we can draw a testable conclusion that small countries should experience more successful rescues, while big countries more failed rescues.

In the subsidy equilibrium there is less monopoly than in the benchmark. Entrydeterring monopoly of firm 2 is more beneficial to welfare in country 1 than blockaded monopoly of firm 2, so government 1 grants a subsidy in order to force firm 2 to deter entry.

The final remark is on the fact, that the government's intervention allows the market to achieve equilibrium also for parameter vectors, for which there is no pure-strategy equilibrium in the benchmark.

\section{$5 \quad$ Welfare analysis}

In this section we study externalities of $R \& R$ subsidy on the welfare distribution under the assumption of linear demand. The subsidy is positive in case of successful rescue, which happens for initial parameter vectors $\left(\alpha, c_{1}\right)$ such that $\tilde{c_{1}}<c_{1}<h\left(c_{1}\right)$, and for failed rescue which happens for initial parameter vectors $\left(\alpha, c_{1}\right)$ such that $h\left(c_{1}\right)<c_{1}<f_{4}$, 
where

$$
h\left(c_{1}\right)=\left\{\begin{array}{lll}
f_{3} & \text { for } & \alpha \in(0,0.24562), \\
f_{2} & \text { for } & \alpha \in(0.24562,0.399563), \\
f_{5} & \text { for } & \alpha \in(0.399563,0.462443), \\
\tilde{c_{1}} & \text { for } & \alpha \in(0.462443,1) .
\end{array}\right.
$$

The first comparison we make across prices.

Corollary 5 Compared with the benchmark equilibrium price, the subsidy equilibrium price increases in successful rescue, but decreases in failed rescue.

In case of successful rescue, duopoly is the outcome. The high-cost firm also produces, which drives the average production cost up. As the result, the price is higher compared with the benchmark and all consumers are harmed. Consumers in country 1 lose even more than those in country 2 , because they additionally have to pay for the subsidy. The gain on firm 1's profit, however, is high enough, so that country 1's welfare is increased. In failed rescue, entry-deterrence of firm 2 is the outcome. The price is then $P\left(x_{2}^{E s}\right)=c_{1}-k_{1}$ and since the subsidy is positive, it is lower then $c_{1}$, which is the price in entry-deterrence in the benchmark. Naturally such $P\left(x_{2}^{E s}\right)$ is also lower than monopoly price, which is the highest of all prices in our model.

Comparing profits leads us to the following

Corollary 6 Industry profits decrease in both successful and in failed rescue.

If the rescue fails, firm 2 has to restructure more aggressively in order to keep firm 1 out of the market. Therefore, its profits are lower than in the benchmark case. In successful rescue, total profit and profit of firm 2 decrease, since firm 2 restructures less than in the benchmark and additionally inefficient firm 1 also produces, so production costs are higher and even the higher price is not able to compensate it.

An example of welfare changes is depicted in Figures 4 and 5. We plot all parts of welfare as a function of $c_{1}$, holding $\alpha$ fixed at two different levels. Dashed lines represent the benchmark model, while continuous lines illustrate the subsidy game.

We can observe the following regularities. Country 1 is always better off. In successful rescue it gains on profit, in a failed rescue it gains on consumer surplus. This is a conse- 


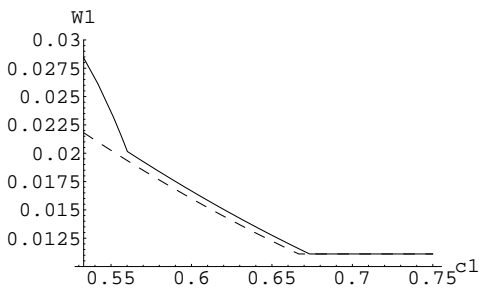

(a) welfare 1

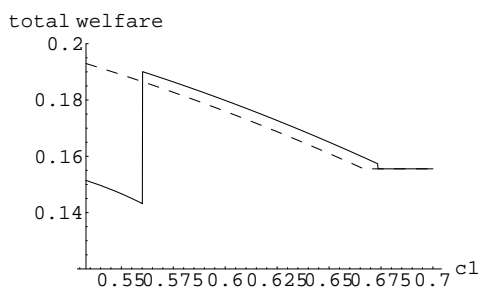

(c) total welfare

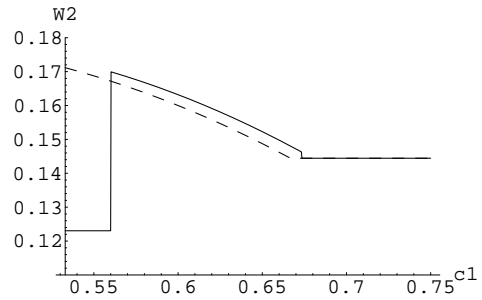

(b) welfare 2

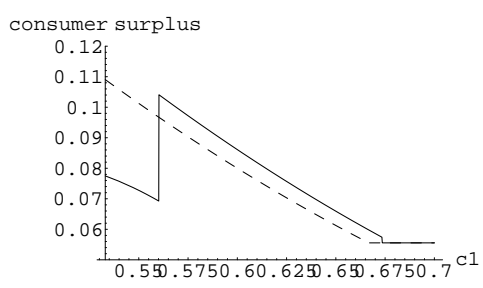

(d) net consumer surplus

Figure 4: Effects of the subsidy for $\alpha=0.2$.

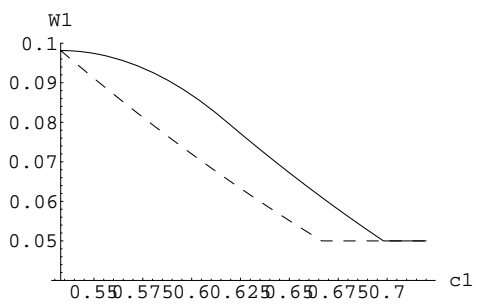

(a) welfare 1

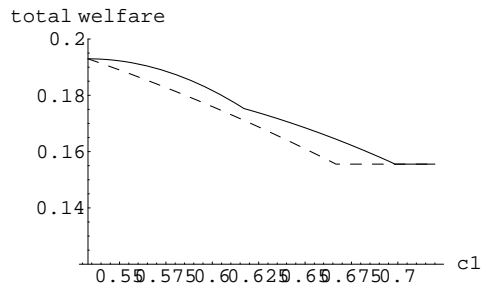

(c) total welfare

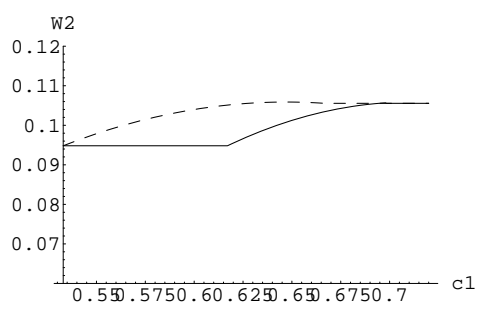

(b) welfare 2

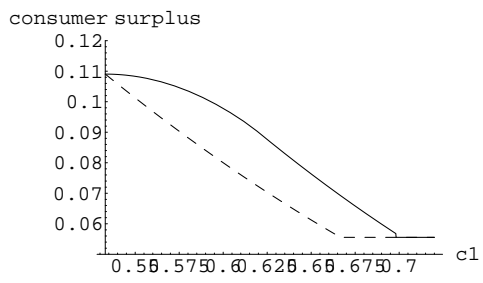

(d) net consumer surplus

Figure 5: Effects of the subsidy for $\alpha=0.85$. 
quence of the game construction: government 1 acts as the first one and by setting $k_{1}=0$ she can always get at least the benchmark welfare. Therefore in the subsidy game she can do better.

Welfare in country 2 increases when consumer surplus increases a lot and country 2's share in consumer surplus in very high. That is the case for failed rescue and low $\alpha$. In a successful rescue consumers are harmed and firm 2 loses market share, so welfare 2 in that case decreases compared with the benchmark. Also when $\alpha$ is high enough, welfare 2 declines since entry-deterring profits are lower and a big part of consumer gain belongs to country 1.

The change in total welfare is a sum of the above two. In case of a successful rescue total welfare drops and this drop is caused mainly by smaller consumer surplus and higher total production cost. In a failed rescue total welfare increases, since the subsidy enforces a lower price and the cost of the subsidy is low enough to make such rescue profitable for consumers.

\section{Conclusions}

Summing up, we showed that depending on the initial cost asymmetry between firms and the asymmetry in countries' share in consumer surplus, rescue and restructure subsidy has one of the following effects: it can save the high-cost firm from the exit and in this way reduce productive and allocative efficiencies in the common market, or it can have a strategic impact on the entry-deterring monopolist and in this way increase allocative efficiency, without preventing exit of the beneficiary.

We find that the role of asymmetry in size is very important: countries with equally inefficient firms, but different shares in consumer surplus, choose very different policies. Roughly speaking, big countries do not prevent exit, while small countries do.

In the airlines industry, governments of several small countries tried to prevent exit of their national champions, e.g. the Greek government granted rescue aid to Olympic Airways and very recently the Commission approved a bailout of Cyprus Airways. These rescues were successful in the bailout, but were likely to keep prices high. The situation 
could be different in case of the Italian government's subsidy for Alitalia. It is still not sure if the exit was prevented, but if Alitalia exits, welfare in both Italy and the whole EC may increase due to lower prices, which come about because other airlines restructure more in the presence of a subsidy, than they would in its absence.

Different behavior of asymmetric firms and countries can be a rationale for the EC control of subsidies. In our model, subsidies which actually succeed in the rescue decrease welfare of all consumers and total welfare. This can be a reason to ban them. On the other hand, subsidies which fail to rescue are welfare improving. Their aim is purely to distort free market, but to the advantage of consumers.

The model of course has its limitations. One of them is lack of dynamics, so that smaller dynamic incentives to invest caused by the subsidy cannot be observed. This effect (called soft budget constraints in the literature) will most likely show up in a dynamic setting and lead to further welfare reduction in case of successful rescues. Another limitation is that governments most likely have other objectives than welfare when rescuing a firm, e.g. jobs, reelection or bribes. These are just two promising ideas for the future work on rescue subsidies. 


\section{Appendix}

\section{Proof of Proposition 2.}

\section{2nd stage: production}

In the second stage, levels of restructuring are already chosen and firms choose their preferred level of production. In a Nash equilibrium, each firm optimizes its profits assuming that output of the other firm is constant.

There are five potential market structures: firm 1 or 2 can be a blockaded monopoly, each can deter entry or finally both firms can produce in duopoly.

Suppose first that firm 2 is more efficient: $0.4-e_{2}<c_{1}-e_{1}$. Monopoly of firm 2 emerges if the best-reply of firm 1 is not to enter, that is when the monopoly price is lower than marginal cost in firm 1:

$$
1-x_{2}^{M}<c_{1}-e_{1}
$$

Since $x_{2}^{M}=\frac{1-\left(0.4-e_{2}\right)}{2},(47)$ reduces to

$$
e_{2}>1.4-2\left(c_{1}-e_{1}\right)=l_{1}\left(e_{1}\right)
$$

Duopoly is the equilibrium if firm 2's duopoly profits are higher than entry-deterrence profits, which reduces to

$$
e_{2}<0.65-\frac{5}{4}\left(c_{1}-e_{1}\right)=l_{2}\left(e_{1}\right)
$$

Otherwise, entry-deterrence by firm 2 is the equilibrium.

Suppose now that firm 1 is more efficient: $e_{2}<0.4-c_{1}+e_{1}=l_{3}\left(e_{1}\right)$. By symmetric reasoning, duopoly will emerge if

$$
e_{2}>0.2-\frac{4}{5}\left(c_{1}-e_{1}\right)=l_{4}\left(e_{1}\right)
$$


and monopoly if

$$
e_{2}<-0.1-\frac{1}{2}\left(c_{1}-e_{1}\right)=l_{5}\left(e_{1}\right)
$$

However, $l_{5}$ is never binding since it is located outside of the rectangle $\mathcal{C}=\left(0, c_{1}\right) \times\left(0, c_{2}\right)$, in which restructuring efforts must be according to our assumptions. It is a consequence of fixing $c_{2}$ low enough.

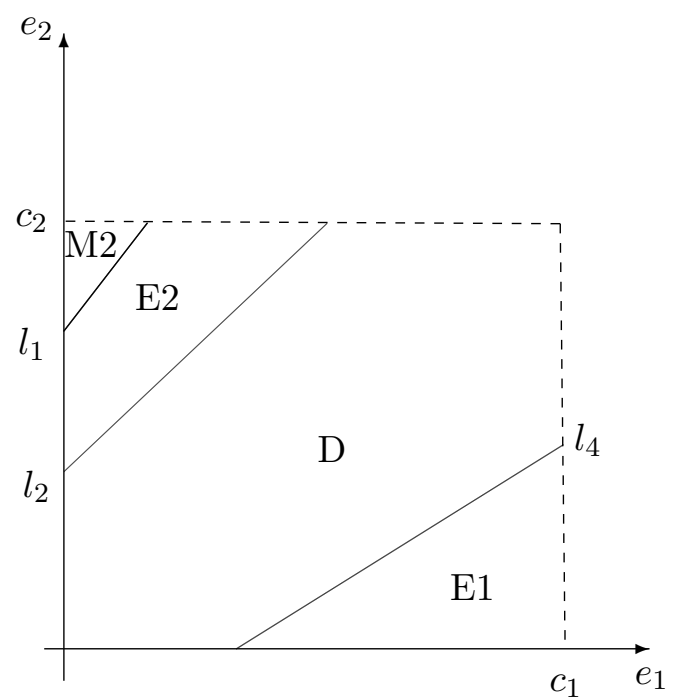

Figure 6: There are four market structures in the equilibrium of the second stage of the benchmark game.

In the M2 area firm 2 is the monopolist, in the E2 area firm 2 deters entry of firm 1, in the D area both firms compete and in the E1 area firm 1 deters entry of firm 2.

\section{1st stage: restructuring}

Knowing the equilibrium outcome of the second stage, firms choose restructuring levels: $e_{i} \in\left(0, c_{i}\right)$. Profits of firms are

$$
\Pi_{2}= \begin{cases}0 & \text { if }\left(e_{1}, e_{2}\right) \in E 1 \\ \frac{1}{9}\left[1-2\left(0.4-e_{2}\right)+\left(c_{1}-e_{1}\right)\right]^{2}-\frac{5}{2} e_{2}^{2} & \text { if }\left(e_{1}, e_{2}\right) \in D \\ {\left[\left(c_{1}-e_{1}\right)-\left(0.4-e_{2}\right)\right]\left(a-c_{1}+e_{1}\right)-\frac{5}{2} e_{2}^{2}} & \text { if }\left(e_{1}, e_{2}\right) \in E 2 \\ \frac{1}{4}\left[1-\left(0.4-e_{2}\right)\right]^{2}-\frac{5}{2} e_{2}^{2} & \text { if }\left(e_{1}, e_{2}\right) \in M 2\end{cases}
$$


and symmetrically

$$
\Pi_{1}= \begin{cases}0 & \text { if }\left(e_{1}, e_{2}\right) \in M 2 \text { or } E 2 \\ \frac{1}{9}\left[1-2\left(c_{1}-e_{1}\right)+\left(0.4-e_{2}\right)\right]^{2}-\frac{5}{2} e_{1}^{2} & \text { if }\left(e_{1}, e_{2}\right) \in D \\ {\left[\left(0.4-e_{2}\right)-\left(c_{1}-e_{1}\right)\right]\left(1-\left(0.4-e_{2}\right)-\frac{5}{2} e_{1}^{2}\right.} & \text { if }\left(e_{1}, e_{2}\right) \in E 1\end{cases}
$$

In order to find a Nash equilibrium, we first find reaction functions. Their location depends on the value of $c_{1} \in(0.4,1)$. We start with the locating best-reply in each market structure separately by solving first order conditions. This is sufficient, since for $d=5$ all profit functions $\Pi_{i}$ are concave in $e_{i}$. Then we compare profits across market structures for a given $e_{j}$, taking into account possible corner solutions, and in this way we identify reaction functions.

In monopoly, the best-reply function is independent of the rival's restructuring:

$$
e_{i}^{M}=\frac{1-c_{i}}{9} \quad \Pi_{i}^{M}=\frac{5\left(1-c_{i}\right)^{2}}{18}
$$

Monopoly of firm 2 is possible when area M2 overlaps the rectangle $\mathcal{C}$, like in the Figure 6. That happens when $l_{1}$ intersects $e_{2}=0.4$ for positive $e_{1}$, which is equivalent to $c_{1}>0.5$. Best-reply $e_{2}^{M}$ overlaps area M2 for $e_{1} \in\left(0, c_{1}-0.6667\right)$. Otherwise, $e_{i}^{M}$ is located below $l_{1}$, so the best-reply in monopoly is a corner solution which for a given $e_{1}$ is closest to $e_{2}^{M}$ and that is $e_{2}=l_{1}\left(e_{1}\right)$.

In entry-deterrence, the best-reply function does depend on the rival's restructuring:

$$
e_{i}^{E}=\frac{1-\left(c_{j}-e_{j}\right)}{5} \quad \Pi_{i}^{E}=\frac{1-\left(c_{j}-e_{j}\right)}{10}\left[1-10 c_{i}+9\left(c_{j}-e_{j}\right)\right]
$$

$e_{2}^{E}$ always cuts $l_{1}$ in the same point as $e_{2}^{M}$ and it cuts $l_{2}$ for $e_{1}=c_{1}-0.428571$. Therefore, for $e_{1}>c_{1}-0.428571$, the highest profit in entry-deterrence brings a corner solution $e_{2}=l_{2}$ and for $e_{1}<c_{1}-0.66667$ a corner solution $e_{2}=l_{1}$.

Finally, the best-reply function in duopoly:

$$
e_{i}^{D}=\frac{4}{37}\left[1-2 c_{i}+c_{j}-e_{j}\right] \quad \Pi_{i}^{D}=\frac{5}{37}\left[1-2 c_{i}+c_{j}-e_{j}\right]^{2}
$$


$e_{2}^{D}$ cuts $l_{2}$ for $e_{1}=c_{1}-0.462687$ and for lower $e_{1}$ the highest duopoly profit available can be achieved by $e_{2}=l_{2}$. $e_{2}^{D}$ cuts $l_{4}$ for $e_{1}=c_{1}-0.196429$ and for higher $e_{1}$ the highest duopoly profit can be achieved by $e_{2}=l_{4}$.

When the rival deters entry or is the monopolist, best-reply is not to restructure at all, since it generates no revenue, but costs.

Finally we can find the reaction function of firm 2 . We choose the best-reply which brings the highest payoff to firm 2 for a given $e_{1}$. For $e_{1}<c_{1}-0.6667$, which in figure 7 is denoted by letter A, it is necessarily $e_{2}^{M}$. Next, we compare $\pi_{2}^{E}$ with monopoly profit on $l_{1}$ and we conclude that firm 2 always prefers to deter entry. Next, we compare optimal entry-deterrence profit $\pi_{2}^{E}$ with optimal duopoly profit $\pi_{2}^{D}$. Duopoly is more profitable for $e_{1}>c_{1}-0.446986$, denoted below as B. For $e_{1}=c_{1}-0.196429$ (point C in figure 7), $e_{2}^{D}$ cuts $l_{4}$. For higher $e_{1}$ the highest duopoly profit for firm 2 is for $e_{2}=l_{4}$. It is the best-reply if it is positive and that happens for $e_{1}$ between points $\mathrm{C}$ and D. Firm 2's reaction function is depicted in red in figure 7 .

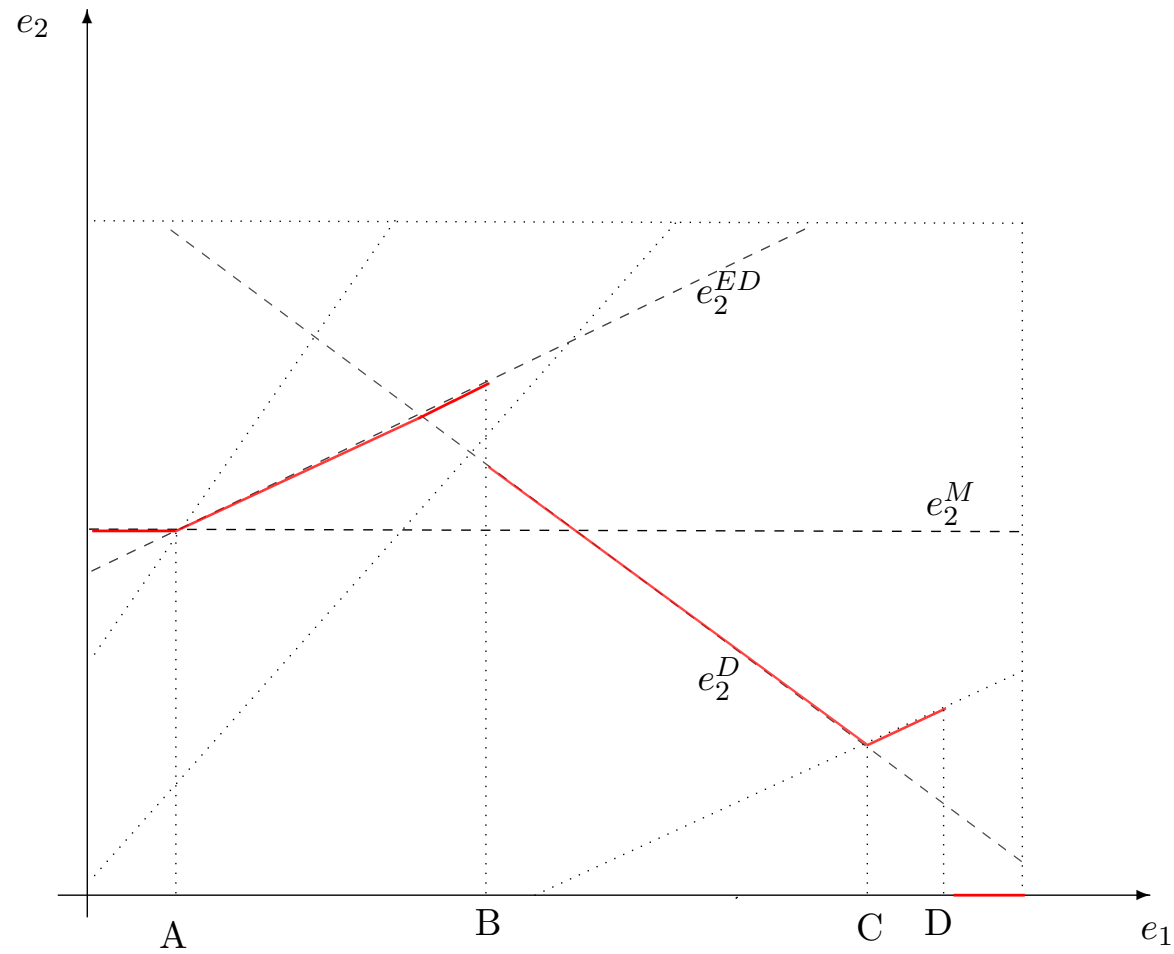

Figure 7: Reaction function of firm 2 is discontinuous.

We find firm 1's reaction function in a similar way. Monopoly is never possible here. $e_{1}^{E}$ 
never intersects area E1, so the best-reply in entry-deterrence is always a corner solution $e_{1}=l_{4}^{-1}\left(e_{2}\right)$. In duopoly, the best-reply is $e_{1}^{D}$ for $e_{2}<0.739286-1.33929 c_{1}=G$ and $l_{2}^{-1}\left(e_{1}\right)$ otherwise. $\mathrm{E}$ is positive when $c_{1}<0.552$.

In order to find firm 1's final reaction function we first compare entry-deterrence profit in the corner solution $e_{1}=l_{4}^{-1}$ with optimal duopoly profits and we find that duopoly is always better. And finally, we check when duopoly profit is positive on $l_{2}^{-1}$. That happens for $e_{2}<0.88476-1.48476 c_{1}=H$, with $\mathrm{H}$ positive if $c_{1}<0.5958$. Otherwise, best-reply of firm 1 is $e_{1}=0$. The reaction function is depicted in red in Figure 8 .

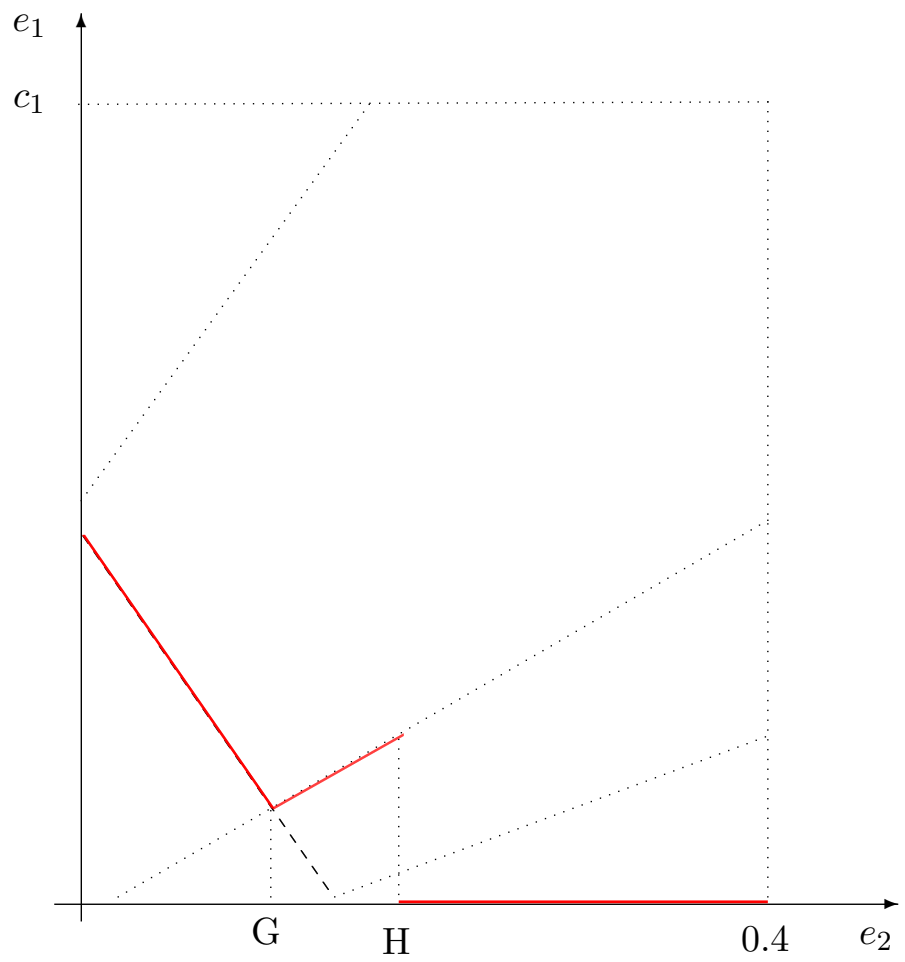

Figure 8: Reaction function of firm 1.

Since we now have the reaction functions, we can look for an equilibrium. If $c_{1}>$ $0.5958, \mathrm{H}$ is negative and firm 1 always prefers not to restructure. If additionally $c_{1}>$ $0.6667=\overline{c_{1}}$, firm 2 is a monopolist, and for $c_{1} \in(0.5958,0.6667)$ it deters entry of firm 1.

For $c_{1} \in(0.55,0.5958) \mathrm{G}$ is negative, but $\mathrm{H}$ positive. Firm 1 undertakes suboptimal duopoly restructuring or no restructuring. No restructuring reaction always cuts $e_{2}^{E D}$ in this $c_{1}$ range, so the outcome here is also entry-deterrence. Down to $c_{1}=0.532987=\tilde{c_{1}}$ the situation is the same, since then $H<e_{2}^{E D}\left(e_{1}=0\right)$ For $c_{1}<0.485749=\underline{c_{1}}$, duopoly 
best-replies intersect in $\mathrm{D}$, so the outcome is duopoly. For $c_{1} \in\left(\underline{c_{1}}, \tilde{c_{1}}\right)$ reaction functions do not intersect (intersect in the point of discontinuity, perhaps mixed strategy equilibrium there).

\section{Proof of Proposition 4.}

We first note that the last two stages of the game are the same as in the benchmark case, with the only difference that firm 1 's initial marginal cost is $c_{1}-k_{1}$. A positive $k_{1}$ moves reaction function $e_{2}^{D}$ down, while pushing $e_{2}^{E}$ and $e_{1}^{D}$ up in the $\left(e_{1}, e_{2}\right)$ space. The lines $l_{1}, l_{2}$ and $l_{4}$ dividing the $\mathcal{C}$ area are all pushed upwards, too:

$$
\begin{aligned}
l_{1 s} & =1.4-2\left(c_{1}-k_{1}-e_{1}\right) \\
l_{2 s}\left(e_{1}\right) & =0.65-\frac{5}{4}\left(c_{1}-k_{1}-e_{1}\right) \\
l_{4 s}\left(e_{1}\right) & =0.2-\frac{4}{5}\left(c_{1}-k_{1}-e_{1}\right)
\end{aligned}
$$

$l_{5 s}$ is still located outside of $\mathcal{C}$.

Best-reply of firm 2 does not change except for replacing $c_{1}$ with $c_{1}-k_{1}$, compared with Proposition 2. Best-reply of firm 1 becomes more interesting, because now marginal cost $c_{1}-k_{1}$ may be also lower than 0.4 .

Monopoly of firm 1 is excluded by the low choice of $c_{2}$, but entry-deterring reaction of firm 1 is now possible. Using the technique form the previous proof, we find that $e_{1}^{E s}$ is best-reply for firm 1 when $e_{2}<0.32169-0.92169\left(c_{1}-k 1\right)$. For $0.32169-0.92169\left(c_{1}-k 1\right)<$ $e_{2}<0.739286-1.33929\left(c_{1}-k_{1}\right)$ best-reply is $e_{1}^{D s}$. For $0.739286-1.33929\left(c_{1}-k_{1}\right)<e_{2}<$ $0.884761-1.48476\left(c_{1}-k_{1}\right)$, the best-reply is a part of the $l_{2}$ line, and for even higher $e_{2}$ it is best for firm 1 not to restructure at all.

The next step in the proof is to find the equilibrium in the second stage of the game, which is where the two best-replies cross. Analogously to the previous proof, we get monopoly of firm 2 when $c_{1}-k_{1}>0.6667$ and entry-monopoly of firm 2 when $0.6667>$ $c_{1}-k_{1}>0.532987$. Duopoly is the equilibrium when both duopoly reaction functions cross in the $\mathrm{D}$ area and this time $e_{1}^{D s}$ is longer than in the benchmark, so we get duopoly for $0.485749>c_{1}-k_{1}>0.299953$. Finally, we get entry-deterrence by firm 1 if $c_{1}-k_{1}<$ 0.229143 . 


\section{1st stage: subsidy}

The first stage of the game is the choice of the optimal subsidy. Government 1 understands perfectly what will happen in the later two stages. Welfare in country 1 is a piecewisedefined function, depending on the value of $k_{1}$. For some values of $c_{1}$ in the benchmark model pure strategy equilibrium does not exist and then we assume that welfare in country 1 is equal to zero. First we calculate welfare for each market structure separately.

When

$$
c_{1}-0.229143<k_{1}<c_{1}
$$

reaction functions cut each other where firm 1 deters entry and firm 2 exits. Welfare in country 1 is

$$
W_{1 s}^{E 1}=\pi_{1}^{E 1}+\alpha C S^{E 1}-\frac{5}{2} k_{1}^{2}=0.275999-0.6 c_{1}+0.6 k_{1}-2.5 k_{1}^{2}+0.18 \alpha
$$

and it is maximized for

$$
k_{1}^{E 1}=0.12
$$

which is independent of any parameter and fulfils condition (60) when

$$
m_{1}=0.12<c_{1}<0.349143=m_{2} .
$$

Since we assumed that $c_{1}>0.4$, we always have $k_{1}^{E 1}<c_{1}-0.229143$. Therefore the government will always choose a corner solution $k_{1}^{E 1 c}=c_{1}-0.229143$, with welfare denoted by a star

$$
W_{1}^{E 1 *}=0.0072479+1.145715 c_{1}-2.5 c_{1}^{2}+0.18 \alpha .
$$

Duopoly is the outcome if

$$
c_{1}-\underline{c_{1}}<k_{1}<c_{1}-0.299953 .
$$


Welfare of country 1 is then equal to

$$
\begin{aligned}
& W_{1 s}^{D}=\pi_{1}^{D}+\alpha C S^{D}-\frac{5}{2} k_{1}^{2}= \\
& \quad=k_{1}^{2}(-1.885155+0.06692 \alpha)+k_{1}\left[c_{1}(-1.229689-0.133849 \alpha)+(0.80402+0.21416 \alpha)\right] \\
& \quad+0.171326 \alpha+0.262855+c_{1}(-0.804027-0.214158 \alpha)+c_{1}^{2}(0.614844+0.0669 \alpha)
\end{aligned}
$$

Optimal subsidy in this case is

$$
k_{1}^{D}=\frac{-0.804028+1.22969 c_{1}-0.214158 \alpha+0.133849 c_{1} \alpha}{0.133849 \alpha-3.77031}
$$

and it fulfils condition (65) when

$$
m_{3}=0.38698+0.034802 \alpha<c_{1}<0.52709+0.029828 \alpha=m_{4}
$$

In this range the government can choose the peak of the welfare parabola and otherwise we have corner solutions. For $\alpha<0.373931$ we have $m_{3}<0.4$, so is this range of $\alpha$ the lower boundary on $c_{1}$ is 0.4 .

Entry-deterring monopoly of firm 2 emerges when

$$
c_{1}-\overline{c_{1}}<k_{1}<c_{1}-\tilde{c_{1}} .
$$

Welfare in country 1 is then

$$
W_{1 s}^{E 2}=-\frac{5}{2} k_{1}^{2}+\frac{1}{2} \alpha\left(1-c_{1}+k_{1}\right)^{2}
$$

and optimal $k_{1}$-the one which fulfils first order condition- is here

$$
k_{1}^{E 2}=\frac{\alpha\left(1-c_{1}\right)}{5-\alpha}
$$

This optimal subsidy fulfils condition (69) when

$$
m_{5}=0.532987+0.0934 \alpha<c_{1}<0.6667+0.06666 \alpha=m_{6}
$$




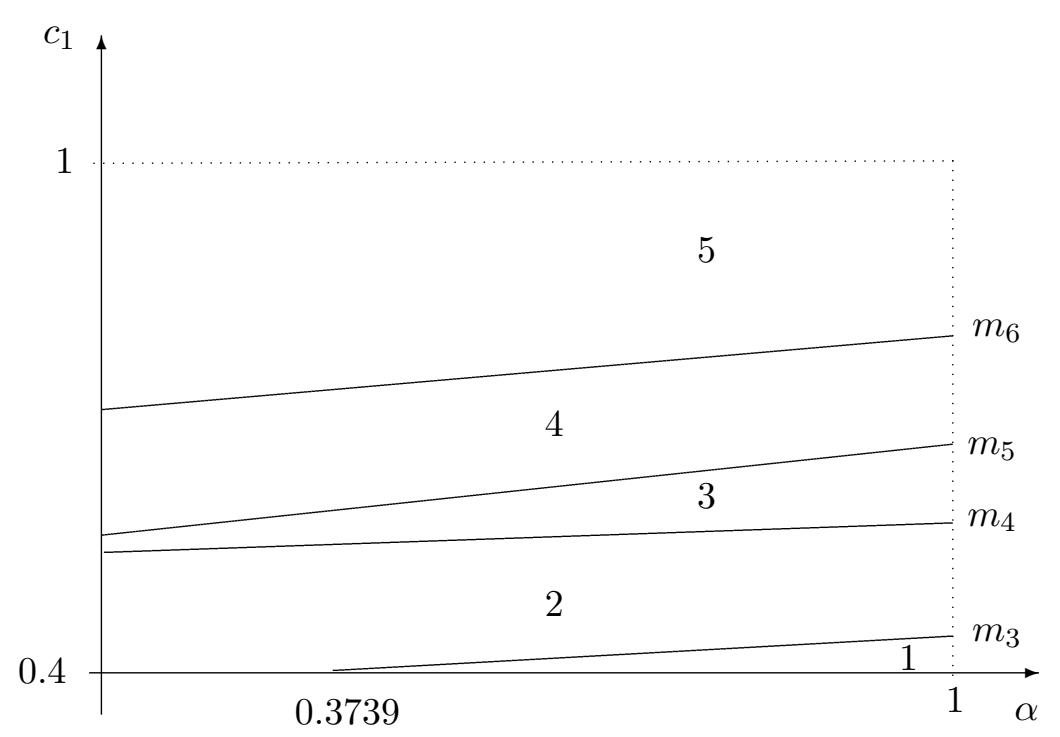

Figure 9: Government has 5 different cases to consider.

Again, in this range the peak of the welfare parabola and otherwise a corner solution is chosen.

Finally, $0<k_{1}<c_{1}-\overline{c_{1}}$ equilibrium market structure is a blockaded monopoly with welfare $W_{1 s}^{M 2}=0.0555556 \alpha$ independent of $k_{1}$.

The government chooses $k_{1} \in\left[0, c_{1}\right]$ depending on $\alpha$ and $c_{1}$. We plot the lines $m_{3}, m_{4}$, $m_{5}, m_{6}$ and $c_{1}=0.4$ in the $\left(\alpha, c_{1}\right)$ space and we notice that there are 5 cases to consider.

- The first case is for $0.4<c_{1}<m_{3}$, it is possible only for $\alpha>0.3739$. Here, the government has a choice between $W_{1}^{E 1 *}, W_{1}^{D}\left(k_{1}=c_{1}-0.299953\right), W_{1}^{E 2}\left(k_{1}=c_{1}-\tilde{c_{1}}\right)$ and monopoly welfare $W_{1}^{M 2}$. Simple calculation shows that $W_{1}^{E 1 *}$ is always the highest, so this is the optimal choice of the government.

- The second case is for $m_{3}<c_{1}<m_{4}$. Here, optimal duopoly choice is possible. The government compares $W_{1}^{E 1 *}$ with $W_{1}^{D}\left(k_{1}^{D}\right), W_{1}^{E 2}\left(k_{1}=c_{1}-\tilde{c_{1}}\right)$ and $W_{1}^{M 2}$ and finds that $W_{1}^{E 1 *}$ is the highest for $c_{1}<\min \left[f_{1}(\alpha), f_{6}(\alpha)\right]$ where

$$
\begin{aligned}
& f_{1}=0.33359+0.0366975 \alpha-0.024098 \sqrt{(\alpha-28.168411)(0.50916+\alpha)} \\
& f_{6}=0.47224+0.0467012 \alpha
\end{aligned}
$$

Duopoly generates highest welfare for $f_{1}(\alpha)<c_{1}<\min \left[m_{4}(\alpha), f_{6}(\alpha)\right]$ and entry- 
deterrence by firm 2 is the best for $\max \left[f_{5}, f_{6}\right]<c_{1}<m_{4}$, where $f_{5}(\alpha)=0.56271+0.02856 \alpha-1.38407 \sqrt{\frac{(\alpha-28.1684)^{2}(\alpha-0.27334)}{153377-5445 \alpha}}$ for $\alpha \in(0.27334,1)$

- The third case is for $m_{4}<c_{1}<m_{5}$. Here, the government chooses the highest of $W_{1}^{E 1 *}, W_{1}^{D}\left(k_{1}=c_{1}-\underline{c_{1}}\right), W_{1}^{E 2}\left(k_{1}=c_{1}-\tilde{c_{1}}\right)$ and $W_{1}^{M 2}$. We check that $W_{1}^{D}\left(k_{1}=\right.$ $\left.c_{1}-\underline{c_{1}}\right)<W_{1}^{E 2}\left(k_{1}=c_{1}-\tilde{c_{1}}\right)$ when

$$
c_{1}>0.5829-0.109912 \alpha=f_{2} .
$$

The line $f_{2}$ divides the area into two parts. To the right of it, the government will choose such $k_{1}$ which will lead to entry-deterrence by firm 2 . To the left there is duopoly.

- The fourth case is for $m_{5}<c_{1}<m_{6}$. Here $k_{1}^{E 2}$ is available. The government compares $W_{1}^{E 1 *}, W_{1}^{D}\left(k_{1}=c_{1}-c_{1}\right), W_{1}^{E 2}\left(k_{1}^{E 2}\right)$ and $W_{1}^{M 2}$ and chooses duopoly if $c_{1}<0.485749++0.10285 \alpha+0.062697 \sqrt{(\alpha-5)(\alpha-0.35357)}=f_{3}$ and $\quad \alpha<0.35357$ or monopoly of firm 2 if

$$
c_{1}>1-0.14907 \sqrt{5-\alpha}=f_{4}
$$

- The final case is for $m_{6}<c_{1}<1$. Here the government chooses the highest of $W_{1}^{E 1 *}$, $W_{1}^{D}\left(k_{1}=c_{1}-\underline{c_{1}}\right), W_{1}^{E 2}\left(k_{1}=c_{1}-\overline{c_{1}}\right)$ and $W_{1}^{M 2}$. For such a high $c_{1}$, it is always most profitable not to subsidize and achieve $W_{1}^{M 2}$.

Putting the choice of the government together, we get Proposition 4 . 


\section{References}

1. Aghion P., M. Schankerman (2004), On Welfare Effects and Political Economy of Competition Enhancing Policies, Economic Journal 114(127), 800-824.

2. Aiginger K., Pfaffermayr (1997), Looking at the Cost Side of "Monopoly", Journal of International Economics 45(3), 245-267.

3. D'Aspremont C., A. Jacquemin (1988), Cooperative and Noncooperative R\&D in Duopoly with Spillovers, American Economic Review 78, 1133-1137.

4. Besley T., P. Seabright (1999), The effects and policy implications of state aids to industry: an economic analysis, Economic Policy 14(28), 13-42.

5. Brander J., B. Spencer (1983), Strategic Commitment with R\&D: the symmetric case, Bell Journal of Economics 14, 225-235.

6. Brander J., B. Spencer (1985), Export Subsidies and International Market Share Rivalry, Journal of International Economics 18, 83-100.

7. Collie D. (2000), State Aid in the European Union: The Prohibition of Subsidies in an Integrated Market, International Journal of Industrial Organization 18(6), $867-884$.

8. Collie D. (2002), Prohibiting State Aid in a Integrated Market: Cournot and Bertrand Oligopolies with Differentiated Products, Journal of Industry, Competition and Trade $2,215-231$

9. Cournot A., Researches into the Mathematical Principles of the Theory of Wealth, Original: L. Hachette, Paris, 1838. English translation by Nathaniel T. Bacon, New York, The Macmillan Company, 1897; reprinted by Augustus M. Kelly, New York, 1971.

10. Dixit A., The Role of Investment in Entry-Deterrence, The Economic Journal 90, $95-106$.

11. Escrihuela-Villar (2004), Innovation and Market Concentration with Asymmetric Firms, CFS Working Paper No. 2004/03. 
12. European Commission, Community Guidelines on State Aid for Rescuing and Restructuring Firms in Difficulty, Official Journal of the European Union, 2004/C $244 / 02$.

13. European Commission, EU competition policy and the consumer, Luxembourg: Office for Official Publications of the European Communities, 2004.

14. Lahiri S., Y. Ono (1988), Helping minor firms reduces welfare, The Economic Journal 98, 1199-1202.

15. Lahiri S., Y. Ono (2004), Trade and Industrial Policy under International Oligopoly, Cambridge University Press.

16. Leathy D., C. Montagna (2001), Strategic Trade Policy with Heterogenous Costs, Bulletin of Economic Research 53:3, 3307-3378.

17. Leathy D., J. P. Neary (1997), Public Policy Towards R\&D in Oligopolistic Industries, American Economic Review 87, 642-662.

18. Mollgaard P. (2004), Competitive Effects of State Aid in Oligopoly, mimeo.

19. Neary J. P. (1994), Cost asymmetries in international subsidy games: should governments help winners or losers?, Journal of International Economics 37, 197-218.

20. Röller L-H., B. Sinclair-Desgagne (1996), On the heterogeneity of firms, European Economic Review 40, 531-539.

21. Schumpeter J. (1942), Capitalism, Socialism, and Democracy, New York: Harper and Row.

22. Spence M. (1984), Cost Reduction, Competition and Industry Performance, Econometrica 52, 101-122.

23. Spencer B., J. Brander (1983), International R\&D Rivalry and Industrial Strategy, Review of Economic Studies 50, 707-722.

24. Vickers J. (1995), Concepts of Competition, Oxford Economic Papers 47, 1-23. 
25. Zhao J. (2001), A Characterization for the Negative Welfare Effects of Cost Reduction in Cournot Oligopoly, International Journal of Industrial Organization 19, 455-469. 
Bücher des Forschungsschwerpunkts Markt und politische Ökonomie

Books of the Research Area Markets and Political Economy

Pablo Beramendi

Decentralization and Income Inequality

2003, Madrid: Juan March Institute

Thomas Cusack

A National Challenge at the Local Level: Citizens, Elites and Institutions in Reunified Germany

2003, Ashgate

Sebastian Kessing

Essays on Employment Protection

2003, Freie Universität Berlin

http://www.diss.fu-berlin.de/2003/202

Daniel Krähmer

On Learning and Information in Markets and

Organizations

2003, Shaker Verlag

Bob Hancké

Large Firms and Institutional Change. Industrial Renewal and Economic Restructuring in France 2002, Oxford University Press

Andreas Stephan

Essays on the Contribution of Public Infrastruc-

ture to Private: Production and its Political

Economy

2002, dissertation.de

Peter A. Hall, David Soskice (Eds.)

Varieties of Capitalism

2001, Oxford University Press

Hans Mewis

Essays on Herd Behavior and Strategic Delegation

2001, Shaker Verlag

Andreas Moerke

Organisationslernen über Netzwerke - Die

personellen Verflechtungen von Führungsgremien

japanischer Aktiengesellschaften

2001, Deutscher Universitäts-Verlag

Silke Neubauer

Multimarket Contact and Organizational Design

2001, Deutscher Universitäts-Verlag

Lars-Hendrik Röller, Christian Wey (Eds.)

Die Soziale Marktwirtschaft in der neuen

Weltwirtschaft, WZB Jahrbuch 2001

2001, edition sigma

Michael Tröge

Competition in Credit Markets: A Theoretic

Analysis

2001, Deutscher Universitäts-Verlag

Torben Iversen, Jonas Pontusson, David Soskice

(Eds.)

Unions, Employers, and Central Banks

2000, Cambridge University Press
Tobias Miarka

Financial Intermediation and Deregulation:

A Critical Analysis of Japanese Bank-Firm-

Relationships

2000, Physica-Verlag

Rita Zobel

Beschäftigungsveränderungen und

organisationales Lernen in japanischen

Industriengesellschaften

2000, Humboldt-Universität zu Berlin

http://dochost.rz.hu-berlin.de/dissertationen/zobel-rita2000-06-19

Jos Jansen

Essays on Incentives in Regulation and Innovation 2000, Tilburg University

Ralph Siebert

Innovation, Research Joint Ventures, and

Multiproduct Competition

2000, Humboldt-Universität zu Berlin

http://dochost.rz.hu-berlin.de/dissertationen/siebert-

ralph-2000-03-23/

Damien J. Neven, Lars-Hendrik Röller (Eds.)

The Political Economy of Industrial Policy in

Europe and the Member States

2000, edition sigma

Jianping Yang

Bankbeziehungen deutscher Unternehmen:

Investitionsverhalten und Risikoanalyse

2000, Deutscher Universitäts-Verlag

Christoph Schenk

Cooperation between Competitors -

Subcontracting and the Influence of Information,

Production and Capacity on Market Structure and

Competition

1999, Humboldt-Universität zu Berlin

http://dochost.rz.hu-berlin.de/dissertationen/schenkchristoph-1999-11-16

Horst Albach, Ulrike Görtzen, Rita Zobel (Eds.)

Information Processing as a Competitive

Advantage of Japanese Firms

1999, edition sigma

Dieter Köster

Wettbewerb in Netzproduktmärkten

1999, Deutscher Universitäts-Verlag

Christian Wey

Marktorganisation durch Standardisierung: Ein

Beitrag zur Neuen Institutionenökonomik des

Marktes

1999, edition sigma 
Jos Jansen

Johan Lagerlöf

Lars Frisell

Sigurt Vitols

Lutz Engelhardt

Antonio Guarino

Steffen Huck

Thomas D. Jeitschko

Thomas Plümper

Vera E. Troeger

Ulrich Kaisera

Pablo Beramendi Thomas R. Cusack Joseph Clougherty

Joseph Clougherty Anming Zhang

Roel C.A. Oomen

Robert J. Franzese,Jr. Jude C. Hays

Albert Banal-Estañol Inés Macho-Stadler Jo Seldeslachts

Oz Shy Rune Stenbacka Jonathan Beck

Michal Grajek

Paul Heidhues Botond Kőszegi

Chiara Strozzi

Olivier Gossner Nicolas Melissas
Partial Information Sharing in Cournot Oligopoly

Lobbying, Information Transmission, and Unequal Representation

Changes in Germany's Bank Based Financial System: A Varieties of Capitalism Perspective

Entrepreneurial Business Models in the German Software Industry: Companies, Venture Capital, and Stock Market Based Growth Strategies of the ,Neuer Markt'

Can Fear Cause Economic Collapse? Insights from an Experimental Study

External Effects of Currency Unions

An Estimated Model of the German Magazine Market

Diverse Disparities: The Politics and Economics of Wage, Market and Disposable Income Inequalities

Antitrust Holdup Source, Cross-National Institutional Variation, and Corporate Political Strategy Implications for Domestic Mergers in a Global Context

Export Orientation and Domestic Merger Policy: Theory and Some Empirical Evidence

Modelling Realized Variance when Returns are Serially Correlated

Modeling International Diffusion: Inferential Benefits and Methodological Challenges, with an Application to International Tax Competition

Mergers, Investment Decisions and Internal Organisation

Price Competition, Business Hours, and Shopping Time Flexibility

Fixed, focal, fair? Book Prices Under Optional resale Price Maintenance

Diffusion of ISO 9000 Standards and International Trade

The Impact of Consumer Loss Aversion on Pricing

Citizenship Laws and International Migration in Historical Perspective

Informational Cascades Elicit Private Information
SP I| 2004- 06

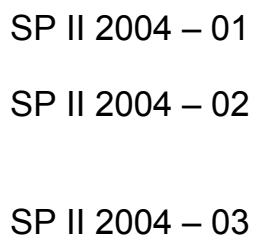

SP || $2004-19$ 
Lutz Engelhardt

Philipp Rehm

Sigurt Vitols Lutz Engelhardt

Sebastian G. Kessing

Kai A. Konrad

Kai A. Konrad Amedeo Spadaro

Joseph A. Clougherty

Talat Mahmood

Sara Geerdes Klaus Schömann

Johannes Münster

Albert Banal-Estañol Jo Seldeslachts

Kai A. Konrad

Johannes Münster

Oz Shy

Kai A. Konrad Stergios Skaperdas

Kai A. Konrad

Dan Kovenock

Thomas Cusack

Torben Iversen

Philipp Rehm

Tomaso Duso

Klaus Gugler

Burcin Yurtoglu

Dan Kovenock

Brian Roberson

Sebastian G. Kessing

Kai A. Konrad

Christos Kotsogiannis
Geschäftsmodelle und nationale Institutionen: Ein

SP || $2005-01$ Vergleich britischer und deutscher Neuemissionen aus der IT-Service - und Softwareindustrie 1996 2002

Citizen Support for the Welfare State: Determinants of Preferences for Income Redistribution

National Institutions and High Tech Industries:

A Varieties of Capitalism Perspective on the Failure of Germany's "Neuer Markt"

Union Strategy and Optimal Income

Taxation

Education, Redistributive Taxation, and

Confidence

The International Drivers of Domestic Airline

Mergers in Twenty Nations: Integrating Industrial

Organization and International Business

Unmet Labour Demand In Europe - Chances for

Immigrants?

Simultaneous Inter- and Intra-Group Conflicts

Merger Failures

SP || $2005-08$

SP || 2005- 09

Silent Interests and All-Pay Auctions

SP || $2005-10$

Lobbying Contests with Endogenous Policy

Proposals

SP || $2005-11$

SP || $2005-12$

Conversion: Theory and Calibration

Succession Rules and Leadership Rents

SP || $2005-13$

Equilibrium and Efficiency in the Tug-of-War

SP || $2005-14$

Risks at Work: The Demand and Supply Sides of Government Redistribution

SP || $2005-15$

EU Merger Remedies: A Preliminary Empirical

Assessment

SP || $2005-16$

Electoral Poaching and Party Identification

SP || $2005-17$

Federal Tax Autonomy and the Limits of

Cooperation 
Jonathan Beck Michał Grajek

Christian Wey

Ela Glowicka
Hypermarket Competition and the Diffusion of Retail Checkout Barcode Scanning

Bailouts in a Common Market: A Strategic Approach
SP || $2005-19$

SP || $2005-20$ 
Bei Ihren Bestellungen von WZB-Papers schicken

Sie bitte unbedingt einen an Sie adressierten Auf-

kleber mit sowie je paper eine Briefmarke im Wert

von 0,51 Euro oder einen "Coupon Reponse Inter-

national " (für Besteller aus dem Ausland)
Please send a self addressed label and postage stamps in the amount of 0.51 Euro or a "CouponReponse International" (if you are ordering from outside Germany) for each WZB-paper requested

Absender I Return Address:

Wissenschaftszentrum Berlin

für Sozialforschung

Presse- und informationsreferat

Reichpietschufer 50

D-10785 Berlin-Tiergarten

Hiermit bestelle ich folgende(s)

Discussion paper(s):

Please send me the following Discussion paper(s):

Bestell-Nr. I Order no.

Autor/in, Kurztitel /Author(s) / Title(s) in brief 